\title{
PENGEMBANGAN METODE PEMBELAJARAN \\ DALAM MENGHADAPI REVOLUSI INDUSTRI 4.0
}

\author{
Maria Sri Hartati \\ Guru SD Negeri 01 Suruh Tasikmadu Karanganyar \\ Email :maria_hartati70@yahoo.co.id
}

\begin{abstract}
ABSTRAK
Metode pembelajaran yang beragam dan membuka keleluasaan guru dalam mengekplorasi peserta didik dan pola pembelajaran yang dijalankan di kelas. Pembelajaran adalah proses interaksi antarpeserta didik,antara peserta didik dan pendidik, dan antara peserta dan sumber belajar lainnya pada suatu lingkungan belajar yang berlangsung secara edukatif, agar peserta didik dapat membangun sikap, pengetahuan dan keterampilannya untuk mencapai tujuan yang telah ditetapkan.Proses pembelajaran merupakan suatu proses yang mengandung serangkaian kegiatan mulai dari perencanaan, pelaksanaan hingga penilaian.Era revolusi industry 4.0 dibutuhkan guru yang mampu meningkatkan kompetensi menuju guru 4.0. guru 4.0 memiliki tanggungjawab yang lebih besar dalam memdidik peserta didik menghadapi revolusi industri 4.0 dan guru harus mampu menguasai dalam pemanfaatan teknologi digital dalam pembelajaran.
\end{abstract}

\section{Kata Kunci : Metode, Pembelajaran, Revolusi Industry 4.0}

\begin{abstract}
Various learning methods opening a freedom for the teachers in exploring pupils and learning pattern applied in the classroom. Learning is an interactive process among the pupils, between the pupils and the teachers, and between the pupils and others sources in a learning environment educationally with the purpose is to make the pupils be able to build their attitude, knowledge, and skill to reach the determined goal. Learning process is the combination process that consist of planning, implementation, and the assessment. Industry revolution era 4.0 needs the teachers who are able to improve the competition to be the teacher of 4.0. The teachers of 4.0 have bigger responsibility in teaching the pupils to face industry revolution 4.0 and they have to master the digital technology implementation in learning.
\end{abstract}

Keywords: Methods, Learning, Industry Revolution 4.0 


\section{PENDAHULUAN}

Pendididkan adalah usaha sadar dan terencanauntuk mewujudkan suasana belajar danproses pembelajaran agar peserta didik secara aktif mengembangkan potensi dirinya untuk memiliki kekuatan spiritual keagamaan, pengendalian diri, kepribadian, kecerdasan, aklak mulia, serta ketrampilan yang diperlukandirinya, masyarakat bangsa dan negara ( undang-undang sisdiknas: 2003)

Perkembangan masyarakat dan perkembangan ilmu pengetahuan yang semakin maju pesat menghasilkan inovasi di berbagai bidang. Perkembangan inovai di bidang ekonomi, social budaya, dan lingkungan dirasakan lebih pesat dibandingkan dengan inovasi di bidang pendidikan. Peningkatan kualitas pendidikan tidak dapat berjalan tanpa adanya inovasi pendidikan. Inovasi pendidikan merupakan upaya dasar dalam memperbaiki aspek aspek pendidikan dalam prakteknya. Dengan kemajuan teknologi yang sangat cepat maka dengan cepat berubah ula berbagai bidang kehidupan. Teknologi berubah, sarana kehidupan berubah, pola tingkahlaku berubah, tata nilai berubah, system pendidikan berubah dan berubah pula sisten pranata social. $\begin{array}{lcr}\text { Masyarakat } & \text { yang } & \text { sedang } \\ \text { membangun akan } & \text { memerlukan inovasi } \\ \text { berupa penemuan } & \text { penemuan baru baik }\end{array}$ berupa gagasan, tindakan atau barang barang baru. Inovasi adalah gagasan, tindakan atau barang yang dianggap baru oleh seseorang, maka ide tersebut merupakan inovasi. Inovasi merpakan pangkal terjadinya perubahan social yang merupaka inti dari perkembangan masyarakat. Di era teknologi dan informasi ini, bukan barang langka, hampir setiap saat muncul penemuanpenemuan baru. Usaha penemuan inovasi ini bertujuan untuk kehidupan yang lebih baik.

Dalam abad teknologi sekarang ini mengajar bukanlah sekedar proses menanamkan pengetahuan atau memberikan stimulus sebayk banyaknya kepada peserta didik tetapi dipandang sebagai proses menanakan pengetahuan kepada peseta didik, tetapi dipandangsebagai proses mengatur lingkungan agar peserta didikbelajar sesuai dengan kemampuan dan potensi yang dimilikinya. Lengkungan sekitar banyak mempengaruhi sikap, dan perilaku masing-masing individu, seperti pola piker, tindakan berbicara sikap gaya bahasa watak dan lain sebagainya. Lingkungan pendidikan terdiri atas rumah 
tangga, sekolah, dan lingkungan lainnya (Yamin: 2008).

Perkembangan pendidikan menurut Eric Ashby mengalami empat revolusi, revollusi pertama, masyakat memberikan wewenang pendidikan terhadap orang-orang tertentu sehingga timbul profesi guru. Revolusi ini mengakibatkan pergeseran pendidikan di rumah dan orang tua kea rah pendidikan formal di sekolah. Revolusi kedua ini berkembang dengan adanya bahasa tulisan dalam penyajian pembelajaran. Revolusi ketiga ditemukan mesin cetak yang pada gilirannya menyebabkan banyaknya buku yang tersedia disekoah sebagai sumber ilmu pengetahuan. Revolusi keempat, teknologi moderan dalam bidang komunikasi dengan produk yang berupa peralatan elektronik dan bahan (software) yang disajikan telah mempengaruhi seluruh sektor kehidupan termasuk pendidikan. Pada revolusi ini telah dimanfaatkan teknologi modern software atau hardware dalam bidang pendidikan.

Perkembangan pendidikan semakin maju pesat abad 21. Abad ke 21 merupakan abad kemajuan ilmu pengetahuan dan kerena teknologi merupakan sutu keharusan dalam menghadapi era globalisasi. Kemajuan teknologi salah satunya adalah teknologi komunikasi yang menunjang proses belajar tanpa batas, seperti pembelajaran mandiri melalui internet.

Saat ini, kita menghadapi revolusi industry keempat yang dikenal dengan revolusi industry 4,0.ini merupakan era inovasi disruptif, di mana inovasi ini berkembang sangat pesat, sehingga mampu membantu terciptanya pasar baru. Inovasi ini juga mampu menggantikan teknologi yang sudah ada. Menghadapi tantangan yang besar tersebut maka pendidikan dituntut untuk berubah juga. Termasuk pendidikan pada jenjang pendidikan dasr dan menengah. Pendidikan 4.0 merupakan pendidkan yang bercirikan pemanfaatan teknologi digital dalam proses pembelajaran atau dikenal dengan system siber (cyber system). System ini mampu membuat proses proses pembelajran dapat berlangsung secara kontinu tanpa batas ruang dan batas waktu.

\section{METODE}

Metode dalam penulisan artikel ini menggunakan analisis deskriptif, terhadap fenomena, gejala yang tampak pada setiap permasalahan/ persoalan yang muncul sebagai suatu alternative pemecahan masalah. 
PEMBAHASAN

Pengertian Pembelajaran, Prinsip Pembelajaran, dan metode pembelajaran dalam Kurikulum 2013

Pembelajaran adalah proses interaksi antarpeserta didik,antara peserta didik dan pendidik, dan antara peserta dan sumber belajar lainnya pada suatu lingkungan belajar yang berlangsung secara edukatif, agar peserta didik dapat membangun sikap, pengetahuan dan keterampilannya untuk mencapai tujuan yang telah ditetapkan.Proses pembelajaran merupakan suatu proses yang mengandung serangkaian kegiatan mulai dari perencanaan, pelaksanaan hingga penilaian.

Selanjutnya menrut kamus bsasar Bahasa Indonesia, Pembelajaran adalah proses interaksi peserta didik dengan pendidik dan sumber belajar pada suatu lingkungan belajar. Pembelajaran merupakan bantuan yang diberikan pendidik agar dapat terjadi proses perolehan ilmu dan pengetahuan, penguasaan kemahiran dan tabiat, serta pembentukan sikap dan kepercayaan pada peserta didik. Dengan kata lain, pembelajaran adalah proses untuk membantu peserta didik agar dapat belajar dengan baik.

Sedangkan dikutip dari laman wikipedia, dinyatakan bahwa pengertian pembelajaran adalah proses, cara, perbuatan menjadikan orang atau makhluk hidup belajar. Pembelajaran adalah proses interaksi peserta didik dengan pendidik dan sumber belajar pada suatu lingkungan belajar. Pembelajaran merupakan bantuan yang diberikan pendidik agar dapat terjadi proses perolehan ilmu dan pengetahuan, penguasaan kemahiran dan tabiat, serta pembentukan sikap dan kepercayaan pada peserta didik. Dengan kata lain, pembelajaran adalah proses untuk membantu peserta didik agar dapat belajar dengan baik (Trisiana, A: 2015).

Secara umum dapat disimpulkan pengertian pembelajaran adalah proses interaksi antara peserta didik/siswa dengan pendidik/guru dan sumber belajar pada suatu lingkungan belajar yang meliputi guru dan siswa yang saling bertukar informasi. Pembelajaran merupakan bantuan yang diberikan pendidik agar dapat terjadi proses pemerolehan ilmu dan pengetahuan, penguasaan kemahiran dan tabiat, serta pembentukan sikap dan kepercayaan pada peserta didik. 
Prinsi-prinsip pembelajaran meliputi: (1) peserta didik difasilitasi untuk mencari tahu, (2) peserta didik belajar dari berbagai sumber belajar, (3) proses pembelajaraan menggunakan pendekatan ilmiah, (4) pembelajaran berbasis kompetensi, (5) pembelajaran terpadu, (6) pembelajaran yang menekankan pada jawaban divergen yang memiliki kebenaran multi dimensi, (7) pembelajaran berbasis keterampilan aplikatif, (8) peningkatan keseimbangan, kesinambungan, dan keterkaitan antara hard-skills dan soft-skills, (9)pembelajaran yang mengutamakan pembudayaan dan pemberdayaan peserta didik sebagai pembelajar sepanjang hayat, (10) pembelajaran yang menerapkan nilainilai dengan memberiketeladanan (ingngarso sung tulodo), membangun kemauan (ingmadyomangunkarso), dan mengembangkan kreativitas pesertadidik dalam proses pembelajaran (tut wurihandayani), (11) pembelajaran yang berlangsung di rumah, di sekolah, dan di masyarakat, (12) pemanfaatan teknologi informasi dan komunikasi untuk meningkatkan efisiensi dan efektivitas pembelajaran, (13) pengakuan atas perbedaan individual dan latar belakang budaya peserta didik, dan (14) suasana belajar menyenangkan dan menantang.

Metode adalah cara dan gaya (method and style) yang digunakan untuk menyampaikan pesan atau informasi kepada komunikan. Adapun yang dimaksud dengan metode disini yaitu cara, teknik atau pendekatan pembelajaran yang digunakan guru dalam menyampaikan materi dalam proses belajar mengajar di sekolah. Kegiatan proses belajar mengajar tidak bisa berjalan dengan sendirinya, tanpa dukungan cara, gaya atau pendekatan yang sangat memadahi. Oleh sebab itu, metode adalah satu kesatuan yang melekat pada diri pribadi guru. Menyadari begitu pentingnya metode, tugas guru sebagai fasilitator berkewajiban dapat menggunakan cara atau teknik penyampaian pesan kepada siswa dengan tepat.

Menurut Hasby Ashydiqih,yang dikutip dalam maxmanroe metode pembelajaran adalah seperangkat cara yang dilakukan guna mencapai tujuan tertentu dalam proses pembelajaran.metode pembelajaran adalah suatu proses penyampaian materi pendidikan kepada peserta didik yang dilakukan secara sistematis dan teratur oleh tenaga pengajar atau guru 
Menstimulus kemampuan peserta didik melalui beragam terobosan metode belajar kontekstualyang mendorong peserta didik berpikir kritis dalam beragam kontek hidup yang nanti dihadapinya, seperti problem besed learning, inquiry besed learning, pendekatan pembelajaran Scince, technology, engineering dan mathematic ( STEM ) dan ragam pendekatamn lainnya. Sehingga tidak sekedar berfokus pada polapola lama dan monoton pada pembelajaran yang minim kreatifitas.

Selama ini kita banyak beranggapan bahwa guru adalah kunci keberhasilan sebuah praktik pembelajaran pada peserta didik, tetapi lupa untuk mengikuti bahwa guru tidak lagi satu-satunya sumber belajar peserta didik. Pola dan metodepembelajran lama sering kali menempatkan guru menjadi satu-satunya sumber belajar dan maha tahu, di dalam ruang kelas seolah melupakan bahwa peserta didik yang merupakan subjek belajar pun sesungguhnya merupakan sumeber belajar rekan sejawatnya.

Metode pembelajaran yang beragam dan membuka keleluasaan guru dalam mengekplorasi peserta didik dan pola pembelajaran yang dijalankan di kelas, diharapkan akan juga memperluas wawasan peserta didik tentang kontekstualisasi ilmu yang didapatkannya di dalam kelas menuju prktik hidup yang dihadapinya nanti sebagai bagian dari realitas hidup. Membuka banyak kesempatan dan peluang kepada peserta didik Untuk mengembangkan cakupan sumber belajar yang dimilikinya, baik dari sumber yang sifatnya tangible maupun intangible.

Menghadapi revolusi industry 4.0 tentu bukan hal yang mudah. Kuantiitas bukan lagi menjadi indicator utama bagi suatu sekolah dalam mencapai kesuksesan, melainkan kualitas lulusannya.

Menurut Andi Cahyono, mendidik generasi melineal tidak bisa dilaksanakan dengan cara konvensional. Sekarang bukan jamannya guru berceramah di depan kelas, namun dalam pembelajaranpeserta didik harus aktif dalam mengejar pengetahuan atau yang lebih dikenal dengan students oriented. Guru haru mampu menciptakan suasana kelas yang dinamis dan memungkinkan peserta didik aktif terlibat dalam pembelajaran.untuk sukses mendidik generasi milenial, guru harus mendidik sesuai dengan karakteristik unik yang dimiliki generasi ini,( Genta: Januari 2019 ) 
Teknologi informasi dan Komunikasi untuk Pembelajaran di Era Revolusi Industri 4.0

Guru sebagai garda terdepan dalam dunia pendidikan, oleh karena itu guru harus meng-upgrade kompetensi dalam menghadapi era pendidikan 4.0. peserta didik yang dihadapi saat ini merupakan generasi milenial yang tidak asing lagi dengan dunia digital.peserta didik sudah terbiasa dengan arus informasi dan teknologi industry 4.0. ini menunjukan bahwab produk sekolah yang diluluskan harus mampu menjawab tantangan indutri 4.0. dengan tantang yang sebesar ini maka guru harus belajar meningkatkan kompetensi sehingga mampu menghadapi peserta didik generasi milenial.

Tantangan terbesar yang dihadapi guru adalah pendidikan dan pembelajaran yang sarat dengan muatan pengetahuan yang mengesampingkan muatan sikap dan ketrampilansebagaimana saat ini akan menghasilkan peserta didik yang tidak mampu berkompetensi dengan mesin. Oleh karena iti guru harus mengurangi dominasi pengetahuan dalam pendidikan dan pembelajaran. Pendidkan dan pembelajaran yang diimbangi dengan karakter dan literasi peserta didik akan bijak dalam menggunakan mesin untuk kemaslahatan masyarakat.

Untuk menghadapi era industry 4.0, diperlukan pendidikan yang dapat membentuk generasi kreatif, inovatif, serta kreatif. Hal tersebut salah satunya dapat dicapai dengan car mengobtimalisapenggunanaan teknologi sebagai alat bantu pendidikan yang diharapkan mampu mengahasilkan output yang dapat mengikuti atau mengubah zaman menjadi lebih baik. Sudah saatnya kita meninggalkan proses pembelajaran yang cenderung mengutamakan hafalan atau sekedar menemukan satu jawaban benar dari soal. Metode pembelajaran harus mulai beralih menjadi proses proses pemikiran yang visioner, termasuk mengasah kemampuan cara berpikir kreatif dan inovatif. Hal ini diperlukan untuk menghadapi berbagai perkembangan teknologi dan ilmu pengetahuan.

Untuk menghadapi tantangan dalam era revolusi industry 4.0 dibutuhkan guru yang mampu meningkatkan kompetensi menuju guru 4.0. guru 4.0 memiliki tanggungjawab yang lebih besar dalam memdidik peserta didik menghadapi revolusi industry 4.0 dan guru harus mampu 
menguasai dalam pemanfaatan teknologi digital dalam pembelajaran.

Kopetensi yang dibutuhakan dalan era pendidikan 4.0 adalahah pertama, ketrampilan berpikrir kritis dan pemecahan masalah ( kritical thinking and problem solving skill ). Kompetensi ini sangat penting dimiliki peserta didik dalam pembelajaran abad 21. Guru 4.0 harus mampu meramu pembelajaran sehingga dpat mengeksplor kompetensi ini dari diri peserta didik.

Kedua guru harus memiliki ketrampilan komunikasi dan kolaboratif (communication and collaborative skill). Sebagai satu kompetensi yang sangat dibutuhkan dalam abad 21, ketrampilan ini harus mampu dikontruksi dalam pembelajaran. Model pembelajaran berbasis teknolodi informasi dan komunikasi harus diterapkan guru, guna mengkontruksi lompetensi komunikasi dan kolaborasi.

Ketiga, ketrampilan berpikir kreatif dan inivatsi (creativity and innovative skill). Revolusi industry 4.0 mengharuskan pesreta didik untuk selalu berpikir dan bertindak kreatif dan inovatif tindakan ini perlu dilakukan agar peserta didik mampu bersaing dan menciptakan lapangan berbasis industry 4.0.
Keempat, literasi teknologi informasi dan kominikasi (information and communication technology literacy). Literasi teknologi informasi dan komnikasi (TIK) menjadi kewajiban bagi guru 4.0. literasi TIK harus dilakukan agar tidak tertinggal dengan peserta didik. Loterasi TIK merupakan dasar yang harus dikuasai guru 4.0 agar mampu menghasilkan peserta didik yang siap bersaing dalam menghadapi revolusi industry 4.0.

Kelima, contektual learning skill. Pembelajaran kontektual merupakan pemblajaran yang sangat sesuai diterapkan guru 4.0. jika guru sudah menguasai literasi TIK, maka pembelajaran kontekstual era pendidikan 4.0 lebih mudah dilakukan. Kondisi saat ini TIK merupakan salah satu konsep kontektual yang harus dikenalkan oleh guru. Materi pembelajaran banyak lontektualnya berbasis TIK segingga guru 4.0 sangat tidak siap jika tidak memiliki literasi TIK. Materi sulit yang abstrak mampu disajikan menjadi lebih riil dan kontektual menggunakan TIK.

Keenam, literasi informasi dan media ( information and media literacy ). Banyak media bersifat social yang digandrungi peserta didik. Media social seolah menjadi media komunikasi yang ampuh digunakan 
peserta didik dan guru. Media social menjadi salah satu media pembelajaran yang dapat dimanfaatkan guru 4.0. kehadiran kelas digital besifat media social dapat dimanfaatkan guru, agar pembelajaran berlangsung tanpa batas ruang dan waktu. Guru harus siap menghadapi era pendidikan meskipn dibukan oleh beban kurikulum dan administrasi yang sangat padat.

\section{Guru Harus Kreatif mengembangkan} Metode pembelajaran

Metode pembelajran digunakan untuk menciptakan suasana kelas yang aktif. Pembelajaran akan membosankan bila guru tidak kreatif. Menciptakan suasana belajar yang aktif menjadi tugas utama guru. Mengajar merupakan tugas utama seorang pendidik (guru, dosen, tutor, instruktur, widyaiswara). Pendidik yang kreatif akan selalu menciptakan ide-ide dalam merancang sistem pembelajaran baru yang mampu membuat peserta didik dapat mencapai tujuan belajarnya dengan penuh rasa puas. Mengajar bukan hanya menyampaikan bahan pelajaran pada siswa tetapi merupakan suatu proses upaya dalam membibing dan memvasilitasi siswa supaya dapat belajar secara efektif dan efisien.
Keberhasilan pembelajaran sangat dioengaruhi oleh proses pembelajaran yang dikembangkan dan menerapkan berbagai metode mengajar dalam mencapai tujuan pembelajaran.

\section{PENUTUP}

Metode pembelajaran adalah suatu pengetahuan tentang cara- cara pembelajaran dipergunakan oleh seorang guru, metode pembelajaran yang digunakan untuk menyampaikan informasi berbeda dengan cara yang ditempuh untuk memantapkan siswa dalam menguasai pengetahuan keterampilan dan sikap. Setiap guru perlu mengetahui dan memahami tentang taraf kematangan dan taraf kesedian belajar seorang peserta didik. Dengan demikian,akan mudah menentukan metode pembelajaran apa yang akan digunakannya.

Guru dituntut untuk menghadapi perkembangan zaman pada era revolusi industri 4,0. Guru harus sigap dalam menyesuaikan diri dengan berbagai pertimbangan yang ada. Diperlukan juga kesiapan sekoalh , peningkatan kapsitas, profesionalisme guru, kurikulum yang dinamis, sarana dan prsarana andal, dan teknologi pembelajaran yang mutahir untuk siap menghadapi era revolusi 4.0. 


\section{DAFTAR PUSTAKA}

Bahri, Djamarah Syamsuk. (2002). Staregi Belajar Mengajar. Jakarta: Rineka Cipta

Daryanto. (2010). Belajar dan Mengajar. Bandung: Yrama Widya.

Depdikbud. (2003). Undang-undang Sistem Pendidikan Nasional. Jakarta: Depatemen Pendidikan Nasional http://pmbs.ac.id/news/Metode_Pembelajara n_Pendidikan_Dalam_Menghadapi_

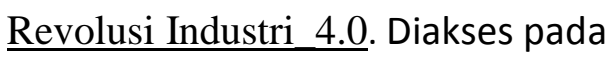
tanggal 16 Juni 2019

https://www.kompasiana.com/lsp3i/5c6dae6 2aeebe123db02d452/metodependidikan-baru-dalam-berdaptasidengan-revolusi-industri-4-0 Diakses pada tanggal 16 Juni 2019

https://aceh.tribunnews.com/2018/11/27/me njadi-guru-era-pendidikan-40.

Diakses pada tanggal 16 Juni 2019

https://id.wikipedia.org/wiki/Pembelajaran https://www.maxmanroe.com/vid/umum/me tode-pembelajaran.html Diakses pada tanggal 16 Juni 2019
https://id.wikipedia.org/wiki/Metode

Majalah Genta no 356 Tahun XIV 05 -19

Februari 2019

Purwodarminto. (1998). Kamus Besar Bahasa Indonesia. Jakarta: Balai Pustaka

Sri Anitah W, dkk. (2009). Strategi Pembelajaran di SD. Jakarta: Universitas Terbuka.

Sumiyati dan Asra. (2008). metode Pembelajaran. Bandung CV Wacana Prima.

Trisiana, A. (2015). The Development Strategy Of Citizenship Education in Civic Education Using Project Citizen Model in Indonesia. Journal of Psychological and Educational Research (JPER), 23 (2), pp. 111-124.

Udin S Winataputra dkk. 2013. Pembaharuan Dalam Pendidikan di $S D$. Jakarta: Universitas Terbuka.

Yamin, H Martinis.2008. Paradigma Pendidikan Kontruktivistik. Jakarta: Gaung Persada Press. 